\title{
A Chaperone: Using Twitter for Professional Guidance, Social Support and Personal Empowerment of Novice Teachers in Online Workshops
}

\author{
Efrat Pieterse \\ The Open University of Israel, \\ Raanana, Israel \\ efratpi@openu.ac.il
}

\author{
Yehuda Peled \\ The Western Galilee College, \\ Acre, Israel
}

YehudaP@wgalil.ac.il

\begin{abstract}
This research examines the feasibility and benefits of using Twitter as a support tool to enhance social interaction among teachers in their first year of service, as they participate in an online induction workshop, and as a tool to aid the workshop's moderator in monitoring the group and enhancing and supporting the early-service teachers' development. The 6914 tweets that were posted during the induction workshop enabled the workshop's moderator to constantly monitor the participants' progress - both their lows and their highs. These tweets reveal a process of socialisation that was taking place among the participants, which led to an increased availability of personal and professional support, and thus enhanced the new teachers' professional growth.

Content analysis was conducted on the 6914 tweets that were posted during the eight months of the induction workshop. Participants answered a feedback questionnaire in the middle, and at the end of the induction workshop. Findings revealed the existence of a process of creating a "community of practice" - a process that creates professional and social support, through its members sharing their feelings and experiences directly from the field. This confirms the claim that tweets on Twitter can be a worthy substitute for face-to-face meetings. However, the questionnaire painted a different picture, in that participants' evaluations of the Tweets were neutral, which raises questions for further research.
\end{abstract}

Keywords: Twitter, early-service teachers, online workshop, teacher empowerment.

Material published as part of this publication, either on-line or in print, is copyrighted by the Informing Science Institute.

Permission to make digital or paper copy of part or all of these works for personal or classroom use is granted without fee provided that the copies are not made or distributed for profit or commercial advantage AND that copies 1) bear this notice in full and 2) give the full citation on the first page. It is permissible to abstract these works so long as credit is given. To copy in all other cases or to republish or to post on a server or to redistribute to lists requires specific permission and payment of a fee. Contact Publisher@InformingScience.org to request redistribution permission.

\section{Introduction}

Twitter is an internet-based service which is designed to transmit short, primarily textual, messages. By writing short messages, users are able to refer to events and share them with others in real time. A Twitter message can contain up to 140 characters and is known as a "tweet".

\section{Editor: Janice Whatley}

An earlier, shorter version of this paper was presented at the Chais conference 2014, in Raanana, Israel, and included in Y. Eshet-Alkalai, A. Caspi, N. Geri, Y. Kalman, V. Silber-Varod, \& Y. Yair (Eds.), Proceedings of the Chais Conference for the Study of Innovation and Learning Technologies 2014: Learning in the Technological Era. Raanana: The Open University of Israel. 
Despite the fact that Twitter is primarily a social network and a communication tool, its potential contributions to education have been examined by a number of researchers in the past few years (Bishop, 2012; Luo \& Franklin, 2012; Luo \& Gao, 2012); some have specifically focused on its role in teacher training (Griffiths, Thompson, \& Hryniewicz, 2010; O'Hare, Quartermaine, \& Cooke, 2011; Tsai, Laffey, \& Hanuscin, 2010). This present research builds on previous research that has been conducted on the support that is provided to beginning teachers during their first year of teaching (Beltman, Mansfield, \& Price, 2011; Kardos \& Johnson, 2010; Zilberstaum, 2013a); it is based as well on reviews of teachers' field experiences that have been published over the past decade (Wang, Odell, \& Clift, 2010; Zilberstaum, 2013a), and on principles of ementoring (Israel, Carnahan, Snyder, \& Williamson, 2013). It examines the Twitter use that took place during an online induction workshop in which the participants - beginning teachers as well as the workshop's moderators - used Twitter as a daily reporting tool.

\section{Teachers During Their Practical Training Year}

The transition from being a student teacher to being a teacher, solely responsible for his or her class, is decisive (Utsumi \& Kizu, 2006). New teachers, during their first year, struggle with their new role; they describe difficulties with class management, in particular, and management within the school in general (Rust, 1994). They describe their need to effectively utilise learning materials and teaching methods and, at the same time, their desire to acclimatise and integrate themselves into a new professional and social environment (Kauffman, Johnson, Kardos, Liu, \& Peske, 2002). Great importance is placed on the supervision and support provided to beginning teachers because, during their first year as teachers, their perceptions of their capabilities and successes or, alternatively, of their failures, are intensified. These often contribute to their eventual decision to remain in the profession or not (Gold, 1996; Johnson \& Birkeland, 2003; Rust, 1994). In Israel, the Ministry of Education has a systematic approach in place for dealing with these difficulties, an approach that is unique to this country (Zilberstaum, 2013a). This approach consists of a combination of several methods of supporting beginning teachers during their first year, including assigning them a mentor within the school where they teach, a 60 -academic-hour practical training, and a specialised induction workshop that is held at a teacher training college of education or at a university. The principal goals of this induction workshop are empowering new teachers in their first year of teaching and firmly establishing their professional strengths via the feedback and reflections offered by the moderator and by their peer group colleagues (Israel's Ministry of Education, n.d. b).

During the workshop, emphasis is placed on analysing teaching experiences, which are brought up by the beginning teachers who participate in the workshop. This is in line with the induction workshops' objectives: "The beginning teachers' reflective thought process with regard to the processes involved in their entering the teaching profession become more refined and a connection is made between theoretical and practical aspects of teaching" (Zilberstaum, 2013a, p. 6).

The induction workshop is defined as a professional support group in which teachers can learn and acquire skills such as class management and integration into the teaching staff. It also acts as a social support group that can encourage personal and professional development and growth, and can provide participants with the sense that they are not alone in dealing with problems related to class discipline, parent-teacher relationships, or perceptions that the system does not accept them, or even adequately use them (Zilberstaum, 2013a).

Over the past few years, due to the workloads of beginning teachers as well as budgetary considerations, some of the induction workshops have been held online, with the workshop moderator meeting participants face-to-face only three times. In these situations, achieving the induction workshop's goals is far from a simple task. 


\section{E-mentoring}

This research examines another aspect of these workshops: personal mentoring. During the past decade, many research papers have proven that the internet, and especially social media, can be used as a tool for remote support. However, the majority of this research has dealt with support for mental health and for general health problems and has concentrated on individual support (see, amongst others, Barak \& Grohol, 2011; Sullivan et al., 2012; Thoits, 2011). However, and especially within the past few years, research has been published illustrating the strength of the internet as a tool that can both support and empower teachers. For example, Quintana and Zambrano from Chile (2014) presented a paper that details the advantages and support that can be gained by teachers in rural and isolated areas, through remote mentoring conducted via e-mail. Israel Smith and others (e.g. Israel et al., 2013; Smith \& Israel, 2010) stress the importance of immediacy and interaction within e-mentoring, as well as the need to provide opportunities for active learning and problem solving through peer discussion and reflection. They also place great emphasis on the choice of technology; in their opinion, the technology used should provide the impression of face-to-face conversation, be easy to learn, be readily available, and have a usable interface.

\section{Research Environment}

The research took place during the 2012-2013 academic year, at a teacher training college located in the north of Israel, and encompassed two online induction workshops which were both moderated by the same person. In order to address the challenges the moderator faced in holding the workshop online, and in order to achieve the workshop goals (as defined by the Israeli Ministry of Education (Israel's Ministry of Education, n.d. c), Twitter was chosen as the social media platform for communication between the beginning teachers and the moderator, as well as for providing instruction and guidance to all workshop participants.

Mentoring within the induction workshops was accomplished via a number of tools that were provided by the college, such as the LMS infrastructure, which included pedagogical and curricular content, as well as forums that were used by the students to present and discuss their field experiences. Despite the availability of these tools, an additional means of fast and direct communication between the mentor and workshop participants was required. The appropriate tool would provide space for the informal, personal, and emotional aspects of the mentoring process. In Israel, Twitter is used less frequently than other types of social media, such as Facebook, but it is also seen as less intimidating with respect to its preservation of users' privacy. It was chosen in this situation as it allows for the fast transfer of short messages, rather than long messages that could bore or confuse the mentor and/or the participants. It is also readily available on all mobile and land devices, and it is easy to use.

Participants were asked to tweet twice a day, every day, using a specific hashtag. Additionally, workshop participants were added to a Twitter list by the moderator for this activity. A Twitter list is a curated group of Twitter users. Anyone can create their own lists or subscribe to lists created by others. Viewing a list timeline will show a stream of Tweets from only the users on that list. By using applications that support Twitter, such as TweakDeck, all participants were able to sort and filter tweets that included the dedicated hashtag or that were sent by defined list members. Thus, they were able to closely follow all relevant activity. All tweets were collected and analysed by the researchers. In order to better understand the effect of constant twitting on the participants of the induction course, the following research questions were formulated:

- To what extent did the daily tweets reflect the Current mood and situation, personal and professional status of workshop participants? What issues did the Tweets address? Has there been a change of issues during the school year? 
- Do twitter tweets represent an appropriate alternative to traditional, face-to-face workshops for beginning teachers?

- What contribution does Twitter make to the work of online workshop moderators?

\section{Methodology}

\section{Instruments}

The research is based on content analysis of the Tweets. For that purpose, content analysis software was used (Narralyzer software). Two main categories were defined: 1. Professional Coping, which included the sub-categories Professional Reflection, Reinforcing factors, and Weakening factors, and 2. Personal Coping.

In order to determine the social interactions which were formed between the participants in the Tweeter-sphere we used the Nodexl, which is a tool for extracting, analyzing and visualizing social media activity and interactions (http://nodexl.codeplex.com/)

In addition, workshop participants completed, at midterm and at the end of the academic year, an online feedback questionnaire that was provided by the moderator. This questionnaire included six open-ended questions. Three that dealt with the use of Twitter and three that concerned participants' views of their profession after their first year of teaching. For this research we examined just the part that dealt with the use of Twitter. Answers were analysed and categorised according to the sentiments they expressed (positive, negative, or neutral). The questions are:

1. Does daily tweeting make a difference in your [professional] life? If yes, please describe it

2. In what way does Twitter influence your interactions with the workshop facilitator?

3. In what way does Twitter influence your interactions with other participants of the workshop?

\section{Participants}

Two groups of first year teachers participated in the workshop (thirty one in total). Their teaching subjects are different and their ages ranged from 23 to 35 years. Most of them had no previous experience of using Twitter.

\section{Procedure}

The research was conducted, for the most part, using a qualitative approach, but some quantitative analysis of the tweets was also carried out. Research questions were formulated during a preliminary study (Peled \& Pieterse, 2013) that was conducted a year prior to the work described here. During the preliminary research, the main issues that emerged from the tweets were identified and the main analytical categories were formulated. During a content analysis of the collected tweets, each category was divided into sub-categories. This process was validated and adapted by three researchers. Using the Narralyzer software, Tweets were sorted by category, subcategory, publication date and name of sender (all names were encoded). The distribution of the tweets by category and sub-category was calculated. Changes over time were also examined: Each category and sub-category was divided into three contiguous segments of ten weeks each: the start of the academic year, the middle of the academic year, and the end of the academic year. The purpose was to identify changes, if any were present, in the topics that were discussed within each segment and in the status and moods of the beginning teachers as they progressed through their first year of teaching. 
Data collection took place between September 2012 and July 2013 - a period of 168 days (tweets were sent only on study days and not during vacations or religious festivals, or on the Sabbath, making the total number of included days only 168).

Ethics: In order to address ethical issues of using Twitter, which is an open social network with searchable content in which users are expected to post tweets which may affect their professional future, the mentor of the induction course explained, at the first face to face meeting with the students, the benefits and the problems of posting in open social networks. The students were advised to adopt a pseudo-name and use that during the induction course rather than their real name. (Those who chose to use a pseudo-name were asked to inform their mentor of their pseudoname.)

\section{Findings}

Question 1: To what extent did the daily tweets reflect the current mood and situation, personal and professional status of workshop participants? What issues did the Tweets address? Has there been a change of issues during the school year?

The average distribution of tweets offers a continuous picture of the daily tweets that were sent throughout the entire workshop. Each workshop participant tweeted, on average, 223 times, or between one and two times per day. The moderator read some 41 tweets each day, using his smartphone, either immediately or soon after they were sent. He was, therefore, able to see daily reflections of the entire group and of each individual participant (Table 1).

Table 1:Tweet Frequency $(n=$ no. of tweets, $d=$ days $)$

\begin{tabular}{lllll}
\hline $\begin{array}{l}\text { Number of be- } \\
\text { ginning teachers }\end{array}$ & $\begin{array}{l}\text { Number of } \\
\text { tweets } \\
(\mathrm{n})\end{array}$ & $\begin{array}{l}\text { Daily average } \\
(\mathrm{d}=168)\end{array}$ & $\begin{array}{l}\text { Average per be- } \\
\text { ginning teacher } \\
\text { per year }\end{array}$ & $\begin{array}{l}\text { Average per be- } \\
\text { ginning teacher } \\
\text { per day }\end{array}$ \\
\hline 31 & 6914 & 41.2 & 223 & 1.3 \\
\hline
\end{tabular}

\section{Issues Addressed in the Tweets}

Following the sorting of tweets into categories, groups of these categories were merged to form two primary categories, each of which was identified as a primary component of the experiences of the beginning teachers. According to this distribution (based on Zilberstaum, 2013b), the two identified primary categories were Professional Coping and Personal Coping (see Table 2). 
Table 2: Category Distribution

\begin{tabular}{llllllll}
\hline Topic & Category & $\begin{array}{l}\text { Start of } \\
\text { year }\end{array}$ & $\begin{array}{l}\text { Middle } \\
\text { of year }\end{array}$ & $\begin{array}{l}\text { End of } \\
\text { year }\end{array}$ & $\begin{array}{l}\text { Total } \\
\text { tweets }\end{array}$ & $\begin{array}{l}\text { distribu- } \\
\text { tion within within total } \\
\text { category } \\
\text { \% }\end{array}$ & $\begin{array}{l}\text { distribution } \\
\text { tweets \% }\end{array}$ \\
\hline $\begin{array}{l}\text { Professional } \\
\text { Coping }\end{array}$ & $\begin{array}{l}\text { Professional } \\
\text { Reflection }\end{array}$ & 241 & 169 & 178 & 588 & $10 \%$ & \\
$\begin{array}{l}\text { Reinforcing } \\
\text { factors }\end{array}$ & 1587 & 1065 & 875 & 3527 & $58 \%$ & \\
\hline $\begin{array}{l}\text { Weakening } \\
\text { factors }\end{array}$ & 774 & 557 & 520 & 1961 & $32 \%$ & \\
\hline $\begin{array}{l}\text { Total Profes- } \\
\text { sional Cop- } \\
\text { ing tweets }\end{array}$ & 2602 & 1901 & 1573 & 6076 & & $88 \%$ \\
\hline $\begin{array}{l}\text { Total Person- } \\
\text { al Coping } \\
\text { tweets }\end{array}$ & 334 & 343 & 152 & 838 & & $12 \%$ \\
\hline Total & 2945 & 2244 & 1725 & 6914 & & \\
\hline \hline
\end{tabular}

\section{Professional coping}

Professional Coping was the main topic that concerned the participants. Included in this category were 6076 tweets, or $88 \%$ of all tweets that were sent. This category was further divided into the following three sub-categories.

Reinforcing factors constituted the most discussed topic $-58 \%$ of all tweets within the Professional Coping category fell into this sub-category. These tweets shared occurrences within teachers' classes or schools, sought professional consultations with peers, and reported successes. For example (The Prefix at the beginning of each quote refers to the participants codes as shown in Figure 3):

$\mathrm{H} 2$ : "I gave a hyperactive student the responsibility to change slides in a presentation. Not only did he do the task well, but he also copied from the board. So simple and so efficient."

M3: "A fast and positive return to normal and to Tweets... (-). Today we had profile discussions and parent meetings, my baptism by fire went successfully. Great!"

Weakening factors constituted 32\% of all tweets within the Professional Coping category. These tweets were expressions of distress, pointing to overload, stress, tiredness and frustration, lack of support or failure. For example:

MM4: "Two hours with the 11th grade on the cell... I really, and I mean really, don't want to face them!!!"

H2: "It's not enough that the Administration doesn't place any importance on team work, but they don't even pay attention to the teaching staff's views and especially those of beginning teachers!

The Administration thinks that they are the main axis around which the rest of the school revolves!"

Professional Reflection (including reflections on "me as a teacher") constituted $10 \%$ of the total tweets within the Professional Coping category. This sub-category contained the following further sub-categories: difficulties and successes, problems dealing with parents, insights regarding events that took place within a teacher's class, feelings and perceptions expressed within the staff room, and support received or desired from the professional environment. For example: 
K1: "I really enjoy individual, one on one teaching, that's where I realize my unfulfilled potential."

D1:"Just as I feel that I got the knack of managing a class, comes a day when the students drive me round the bend."

DD2:"It's amazing to see the difference between the way the educational system and the family regard the student" "As teachers we encounter situations which do not happened at home"

\section{Personal coping}

The second primary category, personal coping, which included tweets that reported on events, feelings and perceptions related to participants' home lives, immediate families and non-workrelated social lives, constituted a relatively small part of the discussion- just $12 \%$ of all tweets.

For example: (M2) "After spending the night with the baby at the ER I went to school as usual. Now I feel how exhausted I am."

(L1) "An exhausting day: worked for eight hours, then gave private lessons and now I'm babysitting three of my cousins' young kids because she's in the hospital."

Table 2 shows that the majority of tweeted discussions were focused on issues directly related to the teaching profession; only a small segment of discussions were devoted to home, personal, or out-of-school events. The low level of discussion focusing on private matters could be attributable to the fact that the majority of tweets were sent during working hours and from school.

\section{Changes over Time in Topics Discussed}

Repeated Measure analysis was used to check differences between trimesters in the topics discussed. It shows that the difference between trimesters is significant (see Table 3). It has been found that Reinforcing Factors and Weakening Factors in the end of the year are higher than at the start of the year and the middle of the year. In other words, there is a linear trend of an increase during the year. The category Professional Reflection shows different behaviour, in that in the middle of the year reflection is higher than at the start of the year and end of the year, lowest at the start of the year. (See Figure 1).

Table 3: Category Distribution per trimester

\begin{tabular}{|c|l|c|c|c|c|}
\hline \multirow{3}{*}{ Professional Reflection } & Variable & $\mathbf{N}$ & Mean & SD & \multicolumn{1}{|c|}{ F } \\
\hline & Start of year & 169 & 2.03 & 0.68 & \multirow{3}{*}{$78.82^{* * *}$} \\
\cline { 2 - 5 } & Middle of year & 169 & 2.63 & 1.21 & \\
\cline { 2 - 5 } & End of year & 169 & 2.19 & 1.05 & \\
\hline \hline \multirow{3}{*}{ Reinforcing Factors } & Start of year & 544 & 2.39 & 0.67 & \multirow{3}{*}{$464.4^{* * *}$} \\
\cline { 2 - 5 } & Middle of year & 544 & 2.90 & 1.10 & \\
\cline { 2 - 5 } & End of year & 544 & 3.18 & 1.17 & \\
\hline \hline \multirow{3}{*}{ Weakening Factors } & Start of year & 520 & 2.73 & 1.25 & \\
\cline { 2 - 5 } & Middle of year & 520 & 3.05 & 1.42 & \multirow{2}{*}{$97.14^{* * *}$} \\
\cline { 2 - 5 } & End of year & 520 & 3.08 & 1.77 & \\
\hline
\end{tabular}

Note: $\mathrm{n}=520,{ }^{*} \mathrm{p}<0.05,{ }^{* *} \mathrm{p}<0.01,{ }^{* * *} \mathrm{p}<0.001$

Professional Reflection: It has been found that the difference between trimesters is significant $\left(\mathrm{F}_{(2,0.99)}=78.82, \mathrm{p}<0.001\right)$. It has been found that Professional Reflection in the middle of the year is higher $(\mathrm{M}=2.63)$ than at the start of the year $(\mathrm{M}=2.03)$ and the end of the year $(\mathrm{M}=2.19)$. Start of year is the lowest. 
Reinforcing Factors: It has been found that the difference between trimesters is significant $\left(\mathrm{F}_{(2,0.99)}=464.4, \mathrm{p}<0.001\right)$. It has been found that Professional Reflection in the end of the year is higher $(\mathrm{M}=3.18)$ than start of year $(\mathrm{M}=2.39)$ and middle of year $(\mathrm{M}=2.90)$. Start of year is the lowest.

Weakening Factors: It has been found that the difference between trimesters is significant $\left(\mathrm{F}_{(2,0.99)}=97.14, \mathrm{p}<0.001\right)$. It has been found that Professional Reflection in the end of the year is higher $(M=3.08)$ than start of year $(M=2.73)$ and middle of year $(M=3.05)$. Start of year is the lowest.

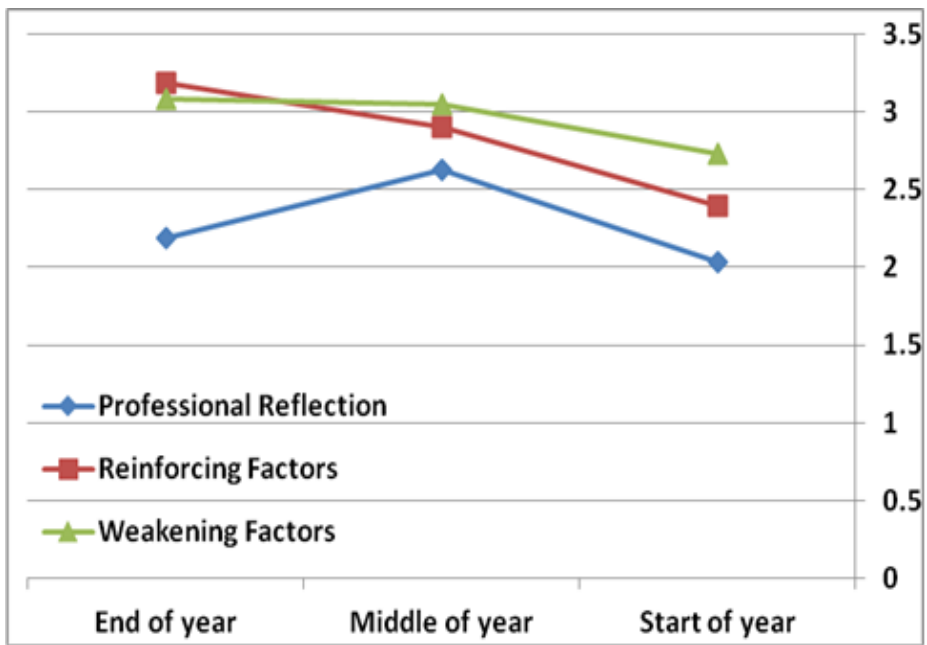

\section{Figure 1: Category Distribution per Trimester within the Profes- sional Coping Category (mean)}

An independent sample T test was used to check differences within the category of Professional Reflection (Table 4). The Professional Reflection Category is composed of 2 sub categories: I have difficulties and I succeed. The difference between this sub categories per trimester is significant $\left(\mathrm{t}_{(586,0.99)}=2.94, \mathrm{p}<0.01\right)$. It has been found that "I have difficulties" category is higher $(\mathrm{M}=1.98)$ than "I succeed" category $(\mathrm{M}=1.77)$ per trimester.

Table 4: Description of difference of Professional Reflection Category

\begin{tabular}{|c|l|c|c|c|c|}
\hline \multicolumn{2}{|c|}{ Variable } & N & Mean & SD & t \\
\hline $\begin{array}{c}\text { Trimester (Start, Middle and } \\
\text { End of year) }\end{array}$ & I have difficulties & 347 & 1.98 & 0.85 & \multirow{2}{*}{$2.94^{* *}$} \\
\cline { 2 - 5 } & I succeed & 241 & 1.77 & 0.81 & \\
\hline
\end{tabular}

Note: $\mathrm{n}=488,{ }^{*} \mathrm{p}<0.05, * * \mathrm{p}<0.01, * * * \mathrm{p}<0.001$

A chronological comparison of tweets within the Professional Reflection sub-category reveals a more detailed picture: At the start of the year, there was a balance between reports of difficulties and reports of successes. Over time, however, reports of difficulties increased, whilst reports of successes decreased (Figure 2). 


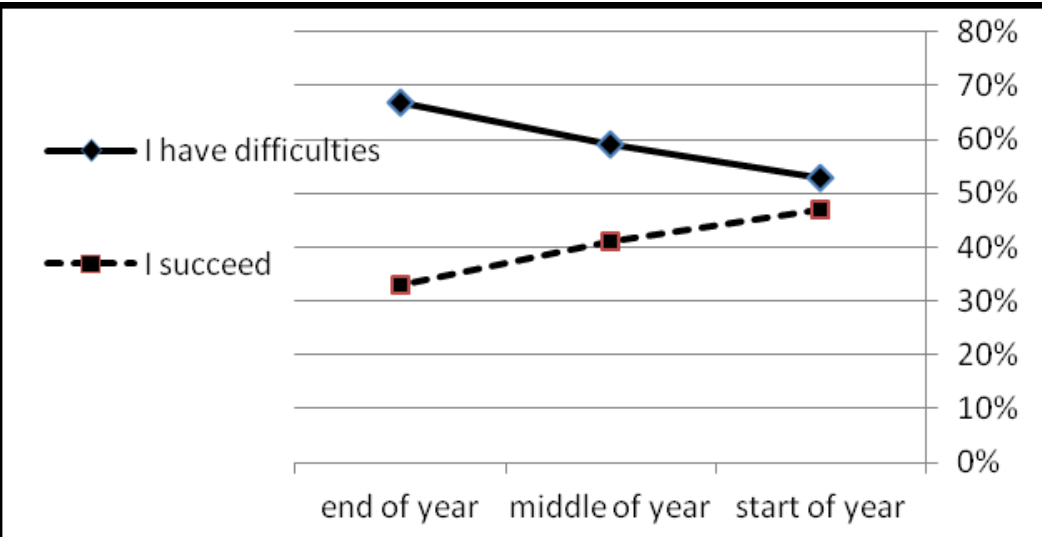

\section{Figure 2: Sub-Category Distribution per Trimester within the Professional Reflection Category (\%)}

Independent sample $\mathrm{T}$ test was used to check differences between categories (see Table 5):

Table 5:Description of difference of the Professional Reflection Category

\begin{tabular}{|c|l|c|c|c|c|}
\hline \multicolumn{2}{|c|}{ Variable } & N & Mean & SD & t \\
\hline \multirow{2}{*}{$\begin{array}{c}\text { Trimester (Start, Middle and } \\
\text { End of year) }\end{array}$} & I have difficulties & 347 & 1.98 & 0.85 & \multirow{2}{*}{$2.94^{* *}$} \\
\cline { 2 - 5 } & I succeed & 241 & 1.77 & 0.81 & \\
\hline
\end{tabular}

Note: $\mathrm{n}=488,{ }^{*} \mathrm{p}<0.05,{ }^{* *} \mathrm{p}<0.01, * * * \mathrm{p}<0.001$

The Professional Reflection Category is composed of two sub categories: I have difficulties and I succeed. The difference between this sub categories per trimester is significant $\left(\mathrm{t}_{(586,0.99)}=2.94\right.$, $\mathrm{p}<0.01)$. It has been found that I have difficulties category is higher $(\mathrm{M}=1.98)$ than I succeed category $(\mathrm{M}=1.77)$ per trimester.

All parameters that were tested indicate significant shift in the participants' mood. This leads us to conclude that the answer to the first question was YES and that using Twitter made it possible to assist them throughout the workshop

\section{Question 2: Do Twitter tweets represent an appropriate alternative to traditional, face-to-} face workshops for beginning teachers?

The objective of induction workshops is to provide beginning teachers with peer support, professional support, and opportunities for personal empowerment. As stated on the Israeli Ministry of Education website (Israel's Ministry of Education, n.d. a.), "The induction workshop constitutes a support group for beginning teaching staff. Its aim is to empower the beginning teacher both on a professional and a personal level. One of the workshop's anticipated results is the development of professionals who believes in themselves and in their ability to cope with professional problems". In a face-to-face workshop, this process would take place through both formal and informal discussions between the participants. This research was carried out to check if a similar process takes place in an online workshop. 


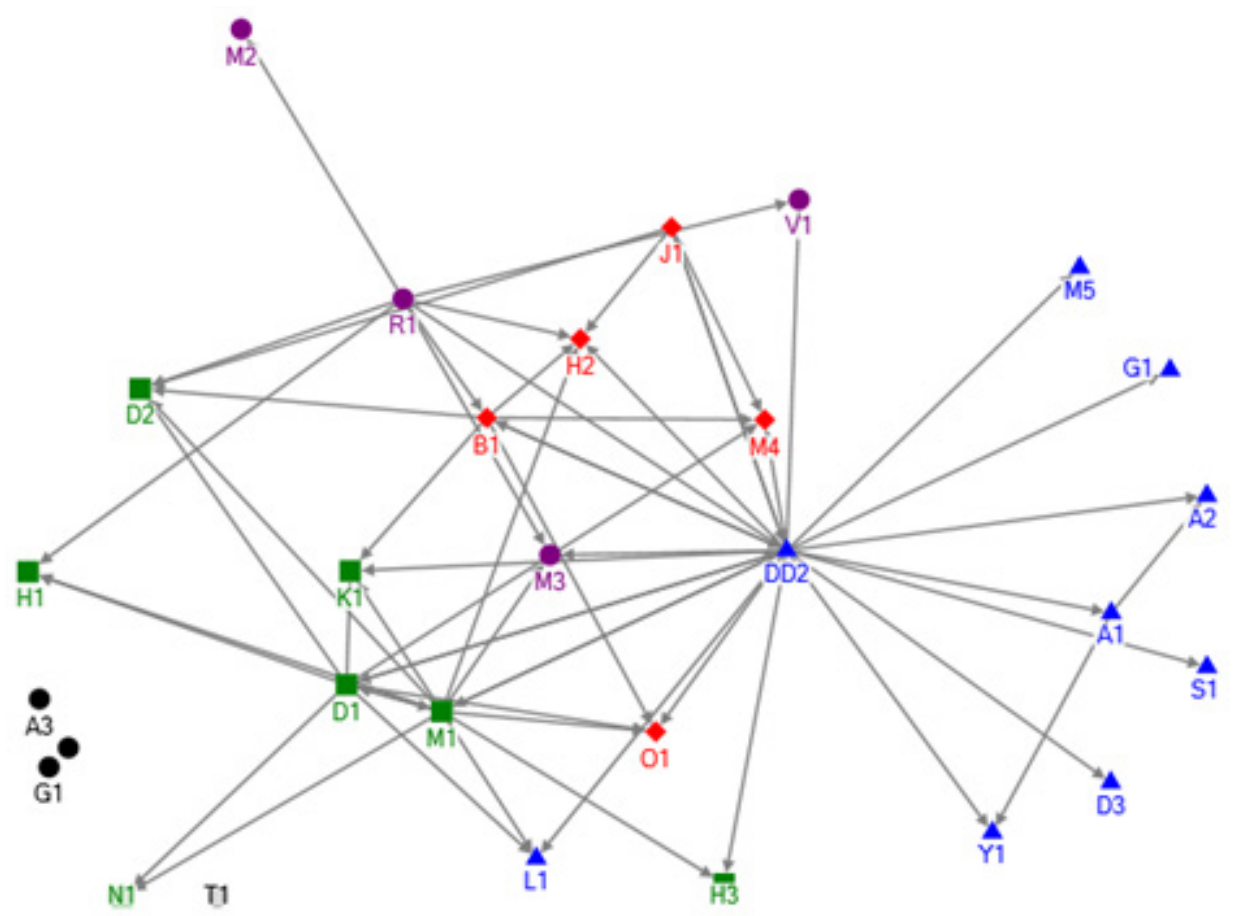

Figure 3: Social Network: Interpersonal Relationship Model

Figure 3 shows members delineated by either a square, a triangle a diamond, or a circle, depending on which group they were in. Codes were assigned randomly to the participants names. The colours represent the various social sub-groups which were formed during the year according to the kind and direction of the interaction between the participants

Group Support: Mapping the interactions and relationships within the beginning teacher group revealed that, over the course of the year, four groups formed within the Twitter framework. Within each group, participants monitored each other and carried on discussions. These discussions included, in most instances, questions, answers, and discussions, which provided informal and internal group support. In face-to-face workshops, such conversations occur during meetings and breaks and are mostly directed by the workshop moderator.

Relationship types were determined by counting the number of participants included in various discussions and by measuring the levels of interaction among participants. Interaction was measured by the use of the "reply" function, and rarely by the use of the "retweet" function. Four distinct communication models emerged to represent the types of interpersonal relationships that formed: diverse, moderate, individual, and no relationship (Table 6). The majority of participants took part in individual or small group relationships (68\%). 19\% participated in diverse relationships, whilst 13\% participated in no relationships whatsoever, and did not interact with either the moderator or their peers via Twitter (although they tweeted every day). In the questionnaire, some stated that they preferred other means of communication, such as the telephone or the course website's forum. 
Table 6: Interpersonal Relationship Models in Twitter

\begin{tabular}{|c|c|c|}
\hline Model & Relationship type & $\begin{array}{c}\text { Relative fre- } \\
\text { quency }\end{array}$ \\
\hline & No relationship & $13 \%$ \\
\hline & $\begin{array}{c}\text { Individual relation- } \\
\text { ships (connected to } \\
2-3 \text { peers) }\end{array}$ & $42 \%$ \\
\hline $\begin{array}{c}\text { Small groups rela- } \\
\text { tionships (connected } \\
\text { to 4-6 peers) }\end{array}$ & $26 \%$ \\
\hline & $\begin{array}{c}\text { Diverse relation- } \\
\text { ships (connected to } \\
7 \text { or more peers) }\end{array}$ & $19 \%$ \\
\hline
\end{tabular}

Professional Support: Numerous conversations between participants and the moderator took place in real time via Twitter, for example:

N1: with anger at the seventh grade pupils, I gave them a pop quiz!!!!

Moderator: Did that help anger? What have the children learned about the role of a quiz in the learning process?

N1: I shelved the quiz. It also a possibility...:-

Another example:

H3: The Subject "cell" so uninteresting to the class so I decided to go through and teach the body systems... We'll start from the gastrointestinal tract.

Moderator: Start from their body. The closest thing and most familiar to them. Slowly descend from the macro until you get into the micro- the cell.

The time between a tweet, which was considered by the moderator as a "cry for help," and its response was, in most cases, less than 10 minutes. This is due to the fact that responses were made via his mobile device, as the moderator followed the groups' tweets around the clock. This illustrates a dynamic process of consultation and professional support unfolding in real time and in immediate response to events. The moderator described this as the "heart of the issue", because the availability of immediate responses to both professional and personal concerns allowed for problems to be attended to as they appeared and before they could grow and explode.

Analysis of the feedback questionnaire showed that, in general, most respondents (46\%) thought that their activity on Twitter contributed to their achieving the workshop's objectives. $26 \%$ said that it contributed somewhat, but not overwhelmingly, whilst $28 \%$ thought that their Twitter activity did not help them whatsoever to achieve those objectives (Table 6).

Personal Empowerment: This is defined here as the beginning teacher's perception of the workshop's contribution to his or her professional advancement and personal welfare (Israel's Ministry of Education, n.d. a). Most participants indicated that tweets on Twitter contributed to their personal empowerment $(57 \%)$. Others $(20 \%)$ thought that Twitter activity had slightly affected them personally, whilst $23 \%$ answered that it had affected them "not at all" (Table 7). 
Most respondents noted that their relationship with the moderator was enhanced by Twitter $(38 \%)$. Some (31\%) thought that Twitter didn't help them to create direct links with the moderator, although they could feel his presence, whilst others (31\%) found that tweeting did not create any real connection between them and the moderator - any connections that were present were superficial. Positive statements on this topic noted that the moderator's daily presence served as a scaffold that gave participants confidence. Statements that were marked as negative mentioned that participants' relationships with the moderator were not significant or that they did not feel him with them (see Table 8 for examples).

Regarding the formation of relationships with peers, participants were divided between those who saw Twitter as an advantage and those who did not. Most (42\%) mentioned that the peer links that were created via Twitter were useful and gave them the feeling of having real social support. $30 \%$ indicated that peer interpersonal communication did not occur at all via Twitter, and $27 \%$ said that personal relationships were indeed formed, but did not go deep enough in that only superficial relationships were formed (See Table 7).

Table 7: Distribution Of Feedback Given by Participants at the End of the Workshop

\begin{tabular}{lccc}
\hline Question (regarding Twitter) & Positive & Neutral & Negative \\
\hline Contribution to personal empowerment & $57 \%$ & $20 \%$ & $23 \%$ \\
\hline Contribution to relationship with moderator & $38 \%$ & $31 \%$ & $31 \%$ \\
\hline Contribution to relationships with peers & $43 \%$ & $27 \%$ & $30 \%$ \\
\hline Total & $\mathbf{4 6 \%}$ & $\mathbf{2 6 \%}$ & $\mathbf{2 8 \%}$
\end{tabular}

Positive statements on this topic mentioned that Twitter was a channel for relief from frustrations and a place to share experiences with friends. In general, these statements described the Twitter activity as meaningful and beneficial, whilst negative statements on this topic described a sense of alienation and lack of contact (see Table 8 for examples).

Table 8: Examples of Statements That Were Rated As Positive, Neutral and Negative

\begin{tabular}{|c|c|c|c|}
\hline Question & Positive statement & Neutral statement & Negative statement \\
\hline $\begin{array}{l}\text { Twitter's contribu- } \\
\text { tion to the participant } \\
\text { (Did daily tweeting } \\
\text { contribute something } \\
\text { to you personally? } \\
\text { What?) }\end{array}$ & $\begin{array}{l}\text { The tweet positively contrib- } \\
\text { utes, on a daily basis, as it al- } \\
\text { lows the participant with some- } \\
\text { thing urgent to say and who } \\
\text { needs to discuss or describe } \\
\text { specific feelings, a channel that } \\
\text { is available and open at all } \\
\text { times. I feel that it primarily } \\
\text { contributes to immediate feed- } \\
\text { back when a critical event has } \\
\text { occurred. } \\
\text { The daily tweet makes an occa- } \\
\text { sional contribution - especially } \\
\text { if I was nervous, then I would } \\
\text { send a tweet immediately on } \\
\text { that specific day. }\end{array}$ & $\begin{array}{l}\text { Most times the tweets } \\
\text { were of no real signifi- } \\
\text { cance and I didn't really } \\
\text { read those that seemed } \\
\text { uninteresting. However, } \\
\text { I did sometimes have } \\
\text { something important to } \\
\text { say and it was nice to } \\
\text { have a forum where I } \\
\text { could write things. }\end{array}$ & $\begin{array}{l}\text { It didn't contribute any- } \\
\text { thing to me but I do } \\
\text { understand that it con- } \\
\text { tributed to you, the } \\
\text { mentor. }\end{array}$ \\
\hline
\end{tabular}




\begin{tabular}{|c|c|c|c|}
\hline Question & Positive statement & Neutral statement & Negative statement \\
\hline $\begin{array}{l}\text { Twitter's contribu- } \\
\text { tion to the partici- } \\
\text { pant's relationship } \\
\text { with the mentor } \\
\text { (Did Twitter activity } \\
\text { contribute to the cre- } \\
\text { ation of a relation- } \\
\text { ship between you } \\
\text { and the mentor? } \\
\text { How?) }\end{array}$ & $\begin{array}{l}\text { I felt free to tweet feelings and } \\
\text { ideas that I had. From your } \\
\text { responses (the mentor) it was } \\
\text { obvious that you had taken note } \\
\text { even if no significant relation- } \\
\text { ship was established. I'm not } \\
\text { sure if such a relationship is } \\
\text { really necessary - from my } \\
\text { point of view it was sufficiently } \\
\text { significant and important. }\end{array}$ & $\begin{array}{l}\text { I didn't feel a direct } \\
\text { connection but knew } \\
\text { that the workshop's } \\
\text { mentor was there for me } \\
\text { and knows what's going } \\
\text { on with me. }\end{array}$ & $\begin{array}{l}\text { I don't feel, from my } \\
\text { side, that the tweet con- } \\
\text { tributed or added any- } \\
\text { thing. It's possible that } \\
\text { the mentor learned to } \\
\text { know me and the other } \\
\text { participants better } \\
\text { through our tweets. }\end{array}$ \\
\hline $\begin{array}{l}\text { Twitter's contribu- } \\
\text { tion to the partici- } \\
\text { pant's relationships } \\
\text { with other partici- } \\
\text { pants } \\
\text { (Did Twitter activity } \\
\text { contribute to the } \\
\text { formation of connec- } \\
\text { tions between you } \\
\text { and the other partici- } \\
\text { pants in the work- } \\
\text { shop? How?) }\end{array}$ & $\begin{array}{l}\text { Working with Twitter "towards } \\
\text { my connection [with] other } \\
\text { workshop participants just by } \\
\text { being part of the "hashtag" } \\
\text { group. This is because every } \\
\text { tweet that expresses my feel- } \\
\text { ings and all of my frustrations } \\
\text { is shared with the entire group } \\
\text { and, when one of them re- } \\
\text { sponds, it increases my sense } \\
\text { of belonging - I feel that the } \\
\text { other members of the group are } \\
\text { interested in what I have to say. } \\
\text { Twitter made feel a part of the } \\
\text { group. Members of the group } \\
\text { always brought up new ideas. } \\
\text { Whenever I did not log in [to } \\
\text { Twitter], I felt as if I was skip- } \\
\text { ping class and missing im- } \\
\text { portant events. }\end{array}$ & $\begin{array}{l}\text { Through tweeting I } \\
\text { learned something about } \\
\text { the other members of the } \\
\text { group. But, you can only } \\
\text { learn a very small } \\
\text { amount about a person } \\
\text { through tweets. } \\
\text { Twitter activity helped } \\
\text { me get to know the } \\
\text { members of the work- } \\
\text { shop but I did not create } \\
\text { deep contact with them. }\end{array}$ & $\begin{array}{l}\text { I can't say that, as a } \\
\text { result of the tweets, any } \\
\text { connections were } \\
\text { formed between me and } \\
\text { the other participants. } \\
\text { Maybe if we had been } \\
\text { familiar with the online } \\
\text { learning group before, } \\
\text { the foundation would } \\
\text { have been strong } \\
\text { enough to communicate } \\
\text { with tweets. It was very } \\
\text { strange to write my } \\
\text { daily experiences to } \\
\text { people I do not know } \\
\text { and to respond to the } \\
\text { experiences of others I } \\
\text { do not feel that personal } \\
\text { connections were built } \\
\text { during the year. }\end{array}$ \\
\hline
\end{tabular}

These findings show that there is no definitive answer to the question of whether Twitter represents an appropriate alternative to traditional, face-to-face workshops for beginning teachers

\section{Question 3: What contribution does twitter make to the work of online workshop modera- tors?}

The moderator of this workshop stressed how vitally important it was for all workshop participants to send short but daily tweets. This way, the moderator could continuously "see" and "hear" what the beginning teachers had to communicate throughout their workdays within their various schools, thus extending the reach of the workshop despite the sparseness of the meetings. Monitoring the tweets allowed the moderator to have his "finger on the pulse" all day and, when necessary, to intervene immediately. When the moderator identified a call for help or signs of distress, he was able to step in and help.

Example:

L1:"I'm so desperate... I don't know what to do tomorrow at school. I hate the thought of going there tomorrow... I don 't want to teach anymore." The moderator's interventions included making direct connections with beginning teachers in crisis, in order to help calm them, and in order 
to collect additional data regarding the events they described. This facilitated communication with the Coordinator of Induction Training at the college, as well as communication with other relevant agents within the schools or within the Inspectorate. The possibility of continuous monitoring is entirely absent in a traditional workshop setting; between meetings, there is almost no communication between the moderator and the beginning teachers who are participating. Therefore, from the moderator's point of view, Twitter provided a significant additional contribution, apart from acting as an alternative to face-to-face meetings. The above finding means that Twitter made it possible for the facilitator to keep an on-going connection, follow and act immediately with the participants and thus achieve the aims, although in long distance.

\section{Discussion}

From the findings of this research, it would appear that daily tweets do show a comprehensive and continuous picture of the professional and emotional processes that are experienced by beginning teachers throughout their induction year. Results identifying issues of concern to them are compatible with the findings described by Zilberstaum (2013a; 2013b). The great benefit they gained from using Twitter lay in the immediacy and authenticity of the messages.

Following the participants' tweets clearly reveals the changes that they went through during the academic year, with regard to each of the categories. The average amount of tweets under the categories "Reinforcing Factors" and "Weakening factors" were seen to increase linearly throughout the period, while "Weakening factors" is higher than "Reinforcing Factors". This can be explained by teachers' exhaustion and fatigue by the end of year (Le Maistre \& Pare, 2010).

Analysis of the category "professional reflection" presents a somewhat different picture. There were fewer reflective tweets in the beginning of the year, a peak in mid-year, and a steep decline towards the end of the year. We suggest the following interpretation. Professional insights develop as participants gather teaching experience and this explains mid-year peak. Towards the end of the year fatigue might influence their motivation to reflect on their insights, since reflection requires an effort, and they prefer simple tweets which do not require deep thought.

The instruction given to tweet a few times each day provided the beginning teachers with a platform from which they could share their experiences with their peer group, i.e., the other participants in the workshop. From this, we can assume that the goal of peer group support was achieved through the use of Twitter. However, analysis of the group relationships that formed (Table 6), and of the feedback that was provided by participants (Table 8), revealed a different picture. Many beginning teachers did not see Twitter as a communication tool, nor did they see the communications that were facilitated through Twitter as direct or significant in relation to their teaching.

Professional Support: Since the role of the induction workshop is to provide beginning teachers with support during their first year as teachers (Zilberstaum, 2013a), professional support is provided within the workshop via interactions with the moderator and discussions of professional matters. Providing support across distance, without the benefit of actual meetings, is not trivial. From the moderator's point of view, the practice of daily tweeting was found to be an efficient tool that allowed for the workshop's professional support goals to be achieved. Screening tools, which gave the moderator the ability to continuously monitor tweets through his smartphone and to respond quickly, allowed for an ongoing professional and supportive discourse, as well as the efficient identification of specific "breaking points" that occurred throughout the year. These crises received an immediate response. This is a unique aspect of Twitter use that provides additional value, since face-to-face workshops do not always allow for the quick identification of such events. 
Personal Development: These processes require personal reflection. The sparseness of personaloriented messages that were sent via Twitter raises the question of whether the goal to enhance participants' personal development was achieved. The researchers assumed that the amount of reflective statements would rise over time and that, towards the end of the year, there would be a significant increase. However, the findings failed to support this assumption (Figure 1). A possible explanation for this is that reflection is a complex process (McIntosh, 2010) that requires more space for content than Twitter provides. Indeed, in the feedback questionnaire, questions related to the teaching profession and to beginning teachers' self-perceptions were answered at great length.

In this case, Twitter provided suitable support for the workshop's two professional goals and it generated supportive and communal discussions among the participants. Added value was found in its role as a provider of continuous professional support that could not be provided by fortnightly face-to-face meetings. According to the feedback questionnaire, however, Twitter did not provide the same sort of social atmosphere that would have been created during face-to-face meetings, thus the inclusion of Twitter in the induction workshop made available a communication tool that served as a suitable alternative to face-to-face meetings.

\section{Conclusion}

The Twitter environment allows for continuous relations between the moderator and beginning teachers who are participating in induction workshops, and it serves as a powerful professional and personal support tool during these teachers' induction year, when they must cope with a new and often difficult and alienating work environment.

Twitter enables the moderator to immediately perceive the state of any workshop participant at any given moment. It serves as an effective solution to challenges of time, efficiency, and immediacy. It also allows for the moderator's immediate response through a variety of other available tools, once the information has reached him or her in real time. This is especially true in times of crisis.

Moderators did need to remain vigilant and alert throughout the entire workshop period, and they can do so by always carrying a smartphone that has been set to receive "popup" alerts when tweets are sent by group members.

These discussions reveal the emergence of a developing professional knowledge community that is continuously acquiring experience. Twitter's ability to transmit professional insights and perceptions to one's peers, as well as its ability to facilitate the fulfilment of requests for support through making available good and immediate advice, represents its function as a tool that bridges differences in time and space. However, it is still doubtful whether Twitter is an appropriate tool for interpersonal communication that is meant to provide support and empowerment; perhaps another form of social media should be considered for this purpose.

Based on the feedback questionnaire and the analysis of the social relationships that were formed during the workshop, it would seem that the use of Twitter did contribute towards the goal of creating a continuous connection between workshop participants and the mentor, but it failed to contribute towards the creation of interpersonal relationships among peers, and it did not allow for lively discussions among participants - which is one of the more telling signs of a productive group.

This research concludes that the use of Twitter contributes towards the goal of creating a community of professional support, but despite this advantage, it lacks features that create a more general community atmosphere. The connections it facilitates are less direct than the ones found in other social networks. However, the findings here suggest that it can be of benefit to form a group for 
each internship year, and that most likely these groups will be perceived as places for members to receive and offer support and advice from peers as well as mentors.

Since Twitter's characteristics differ from those of other social media frameworks, such as Facebook, Google+ or WhatsApp, and since new tools for social media are constantly being developed, it is important to consider all that is available and to choose the technologies that will be appropriate for each new academic intake.

This study is part of a sequence of studies that have taken place over many years and that have focused on the connections among media, social media, teaching needs, and learning needs. This study's possible contribution is its examination of a common form of social media as a tool for creating a professional community. Conclusions drawn from this study can also be applied to the field of knowledge management within organisations and to processes related to interns in various fields. Since the study examined a relatively small and unique group, we suggest the study is continued to examine the suitability of other tools for the purposes that were stated here and to create guidelines for these types of activity that are grounded in appropriate pedagogical principles.

\section{References}

Barak, A., \& Grohol, J. M. (2011). Current and future trends in Internet-supported mental health interventions. Journal of Technology in Human Services, 29, 155-196.

Beltman, S., Mansfield, C., \& Price, A. (2011). Thriving not just surviving: A review of research on teacher resilience. Educational Research Review, 6(3), 185-207.

Bishop, M. (2012). Virtual teacher talk: Blogging with and by pre-service teachers (Dissertation submitted to the education faculty of Lindenwood University). Retrieved August 25, 2014, from http://gradworks.umi.com/3426991.pdf

Gold, Y. (1996). Beginning teacher support: Attrition, mentoring, and induction. In J. Sikula, T. J. Buttery, \& E. Guyton (Eds.), Handbook of research on teacher education (2nd ed., pp. 548-594). New York: Simon \& Schuster Macmillan.

Griffiths, V., Thompson, S., \& Hryniewicz, L. (2010). Developing a research profile: Mentoring and support for teacher educators. Professional Development in Education, 36(1-2), 245-262.

Israel, M., Carnahan, C. R., Snyder, K. K., \& Williamson, P. (2013). Supporting new teachers of students with significant disabilities through virtual coaching: A proposed model. Remedial and Special Education, 34(4), 195-204.

Israel's Ministry of Education. (n.d. a). Induction workshops [in Hebrew]. Retrieved from http://cms.education.gov.il/EducationCMS/Units/Staj/Mitmahim/MeidaAlsadnaot

Israel's Ministry of Education. (n.d. b). Teachers' administration [in Hebrew]. Retrieved from http://cms.education.gov.il/EducationCMS/Units/Staj/Mitmahim/MeidaAlsadnaot/Patich.htm

Israel's Ministry of Education, (n.d. c). Teacher training [in Hebrew]. Retrieved from http://cms.education.gov.il/EducationCMS/Units/Staj/Mitmahim/MeidaAlsadnaot [Hebrew]

Johnson, S. M., \& Birkeland, S. E. (2003). Pursuing a "sense of success": New teachers explain their career decisions. American Educational Research Journal, 40(3), 581-617.

Kardos, S. M., \& Johnson, S. M. (2010). New teachers' experiences of mentoring: The good, the bad, and the inequity. Journal of Educational Change, 11(1), 23-44.

Kauffman, D., Johnson, S. M., Kardos, S. M., Liu, E., \& Peske, H. G. (2002). “Lost at sea'”: New teachers' experiences with curriculum and assessment. Teachers College Record, 104(2), 273-300.

Le Maistre, C., \& Pare, A. (2010). Whatever it takes: How beginning teachers learn to survive. Teaching and Teacher Education, 26(3), 559-564. 
Luo, T., \& Franklin, T. (2012). "You got to be follow-worthy or I will unfollow you!” Students' voices on Twitter integration into classroom settings. In P. Resta (Ed.), Proceedings of the Society for Information Technology \& Teacher Education International Conference 2012 (pp. 3685-3688). Chesapeake, VA: AACE. Retrieved August 25, 2014, from http://www.editlib.org/p/40173

Luo, T., \& Gao, F. (2012). Designing microblogging-based class activities. In P. Resta (Ed.), Proceedings of the Society for Information Technology \& Teacher Education International Conference 2012 (pp. 2939-2944). Chesapeake, VA: AACE. Retrieved August 25, from http://www.editlib.org/p/40037

McIntosh, P. (2010). Action research and reflective practice: Creative and visual methods to facilitate reflection and learning. Routledge.

O'Hare, S., Quartermaine, L., \& Cooke, A. (2011). Issues involved in supporting preservice teachers' learning in an online environment. In Developing student skills for the next decade: Proceedings of the 20th Teaching and Learning Forum, 1-2 February 2011. Perth: Edith Cowan University. Retrieved August 25, 2014, from http://otl.curtin.edu.au/events/conferences/tlf/tlf2011/refereed/ohare.pdf

Peled, Y., \& Pieterse, E. (2013, March). "Is there anybody out there": Twitter as a support environment for first year teachers' online induction workshop. In Society for Information Technology \& Teacher Education International Conference (Vol. 2013, No. 1, pp. 1405-1410).

Quintana, M. G. B., \& Zambrano, E. P. (2014). E-mentoring: The effects on pedagogical training of rural teachers with complex geographical accesses. Computers in Human Behavior, 30, 629-636.

Rust, F. O. (1994). The first year of teaching: It's not what they expected. Teaching and Teacher Education, 10(2), 205-217.

Smith, S. J., \& Israel, M. (2010). E-mentoring: Enhancing special education teacher induction. Journal of Special Education Leadership, 23(1), 30-40

Sullivan, S. J., Schneiders, A. G., Cheang, C. W., Kitto, E., Lee, H., Redhead, J., ... McCrory, P. R. (2012). 'What's happening?' A content analysis of concussion-related traffic on Twitter. British Journal of Sports Medicine, 46(4), 258-263.

Thoits, P. A. (2011). Mechanisms linking social ties and support to physical and mental health. Journal of Health and Social Behavior, 52(2), 145-161.

Tsai, I.-C., Laffey, J. M., \& Hanuscin, D. (2010). Effectiveness of an online community of practice for learning to teach elementary science. Journal of Educational Computing Research, 43(2), 225-258.

Utsumi, L., \& Kizu, J. (2006). Mentoring alternative certification teachers: Perceptions from the field. National Association for Alternative Certification Online Journal, 1(1), 48-67.

Wang, J., Odell, S. \& Clift, R. (Eds.) (2010). Past, present, and future research on teacher induction: An anthology for researchers, policy makers, and practitioners. Lanham, MD: Rowman and Littlefield Education and the Association of Teacher Educators.

Zilberstaum, S. (2013a). Policies of the Department for Specialization and Teacher Induction. In S. Shimoni \& O. Avidav-Unger (Eds.), On the continuum: Training, induction, and teachers' professional development - Policy, theory, and practice (pp. 95-100). Tel-Aviv, Israel: Ministry of Education and the Moffet Institute. [Hebrew]

Zilberstaum, S. (2013b). The induction stage into the teaching profession. In S. Shimoni \& O. AvidavUnger (Eds.), On the continuum: Training, induction, and teachers' professional development - Policy, theory, and practice (pp. 101-131). Tel-Aviv, Israel: Ministry of Education and the Moffet Institute. [Hebrew] 


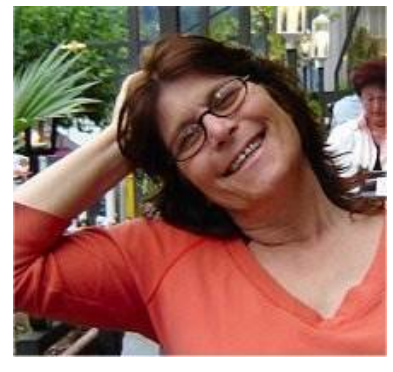

schools.

\section{Biographies}

Efrat Pieterse is the head of the Centre for Advancement in Academic Teaching and a faculty member in the Department of Information Studies at The Western Galilee College in Israel. She also teaches educational technologies at the Open University of Israel.

She holds a BA and MA (com laude) in Educational Technology and a $\mathrm{Ph}$.D. in Information Studies from Bar Ilan University. She has over 10 years' experience in the development and implementation of distance learning systems and educational databases for junior high and high

Her research interests are in the field of the Information Society and its impact on learning.

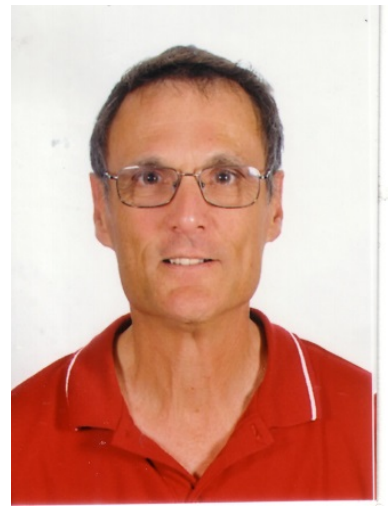

Yehuda Peled is the head of the information studies department at the Western Galilee College - Israel.

His research interests include the use of collaborative environments in teaching and learning, various aspects of online and F2F academic dishonesty, Cyberbullying as well as organizational aspects of technology adoption in education. 